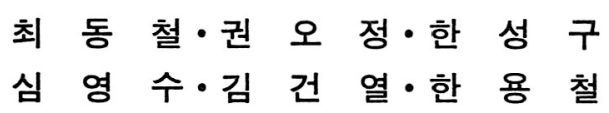

진단방사선과학교실

임 정 기

흥부외과학교실

성

숙 환

해부병리과학교실

서 정 욱

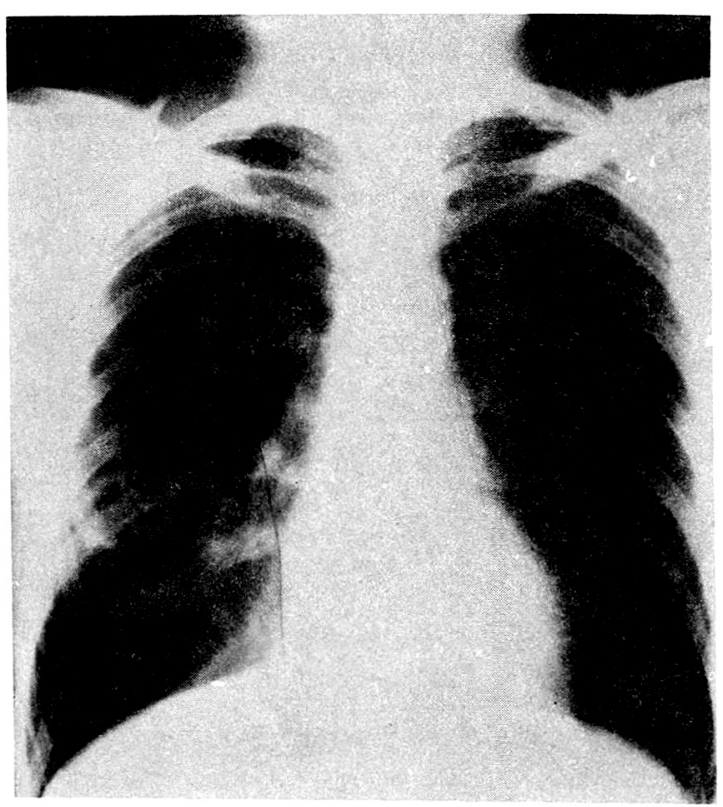

Fig. 1. Initial chest PA showing thin walled cavity with irregular internal margin in right lower lung field.

There was neither mediastinal mass nor hilar prominency. 
초간 노력성호기량 $\left(\mathrm{FEV}_{1}\right)$ 은 $3.69 \mathrm{~L}$ 였으며 폐확산능은 예측치의 $95.5 \%$ 였다.

향부 X선검사상 우측폐의 하엽에 불규칙적인 내부연 을 가지는 벽이 비교적 얇은 공동성 병변이 발견되었고, 그 크기는 6개월전보다 커져있었다(Fig. 1,2,3).

홍부 전산화단층촬영을 시행하였고, 6 개월전의 사진 과 비교해 보면, 그 크기가 증가된 공동성 병변이 우하 엽의 상구역(superior segment) 및 기저구역 (basal segment)에서 발견되었다. 공동의 벽은 대체로 얇았으 나 일부 두꺼운 부분이 공존하였는데, 그 내부연은 불규 칙하게 보였고 과거 사진과 비교해 볼대 공동의 크기는 더 커졌으며, 공동의 주위에 염증소견은 없었고 폐의 다 른 부위와 종격동의 림프절에는 이상소견이 없었다.

환자는 공동성 폐암의 임상적 진단하에 1989년 8월 3 일 우측폐 하엽의 절제술을 시행받았고, 병리조직검사 상 원발성 폐선암으로 진단되었다.

\section{고 찰}

공동을 형성하는 폐질환으로는 폐결핵에 의한 공동, 세균감염에 의한 폐농양, 기관지 낭종등의 양성질환과 악성종양이 있는데, 최근 항생제의 발달로 세균감염에 의한 폐농양이나 괴사성 폐염은 점차 감소하는 추세에 있다 ${ }^{1,2)}$. 폐암은 구미지역에서는 발생율 및 치사율이 가 장 높은 암으로 ${ }^{3)}$, 우리나라에서도 남자에서는 위암, 간 암, 다음으로 흔한 암이다 ${ }^{4}$. 연령별로는 50 대와 60 대에 서 가장 많이 발생하며 젊은층에서는 비교적 드물어, 외 국에서는 40 세미만의 약년자 폐암의 빈도가 전체 폐암환 자의 $1.2 \sim 14 \%$ 로 보고되고 있으며, 국내에서는 김등이 $11.1 \%$, 유등이 $7.0 \%$ 라고 보고하였다5).

세포형에 따른 발생빈도는 보고자에 따라서 차이는 있 으나, 대개 편평상피 세포암이 가장 많고 소세포암과 선 암이 그다음으로 많다고 보고되고 있다6).

폐의 악성종양에서 공동이 발생되는 기전에 대해서는 다음의 여러 학설이 있는데 ${ }^{1,2,7)}$,

첫째, 종양에 의한 기관지폐색으로 인하여 그 원위부 에 만성폐염이나 폐농양이 생겨 폐괴사가 일어나는 경 우, 둘째, 종양에 의한 기관지폐색으로 그 원위부에 대 기포성 기종 (bullous emphysema) 이 생기고 그 기종의 벽을 따라 종양이 퍼져 해면상의(carvenous) 병변을 만 드는 경우, 셋째, 세균감염 없이 종양의 급격한 크기의
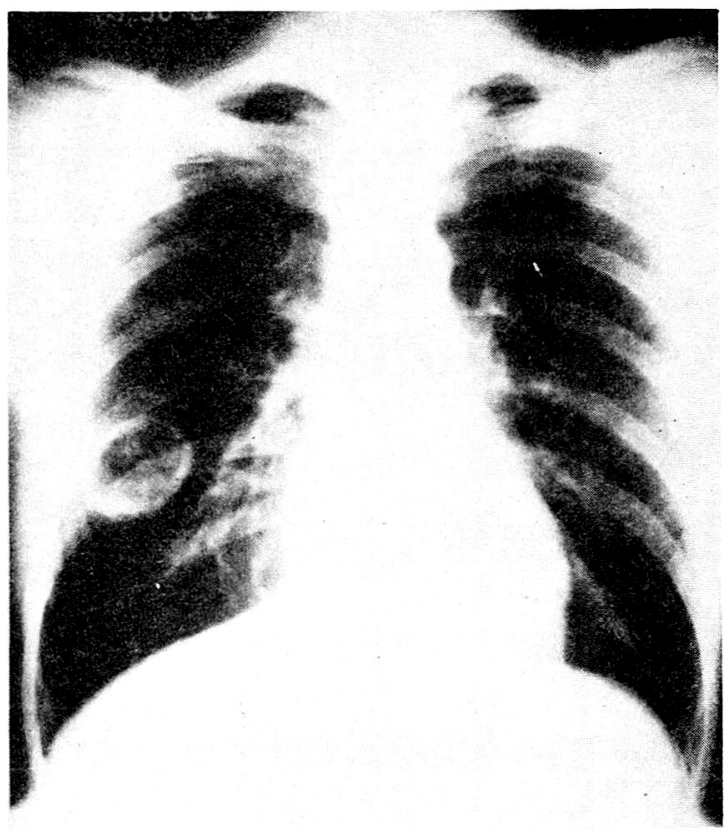

Fig. 2. Chest PA, 6 months later, showing slight increase in the size of cavity.

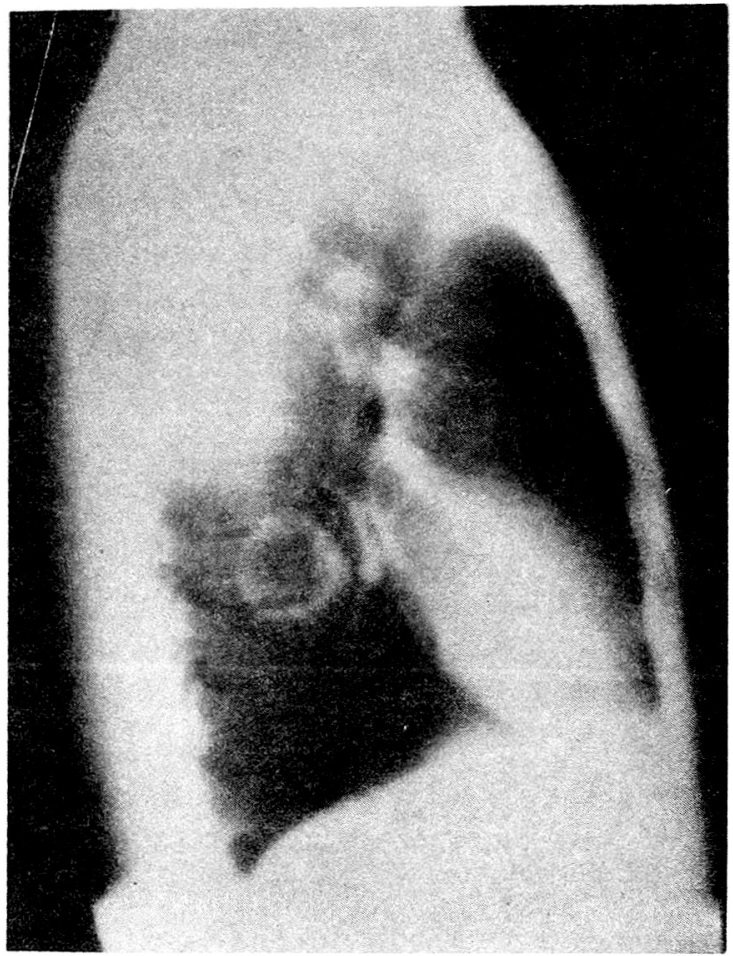

Fig. 3. Lateral film, 6 months later. 


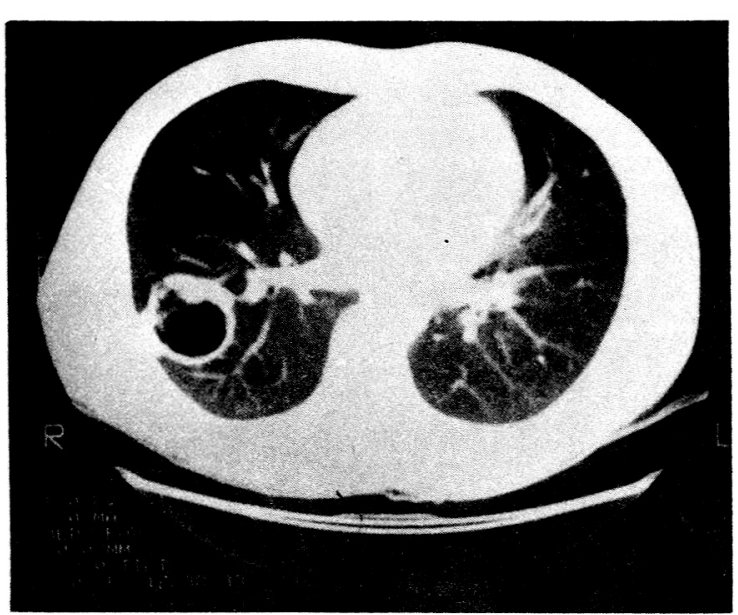

Fig. 4. Chest CT showing thin walled cavity with irregular internal margin in the lower lobe of right lung.

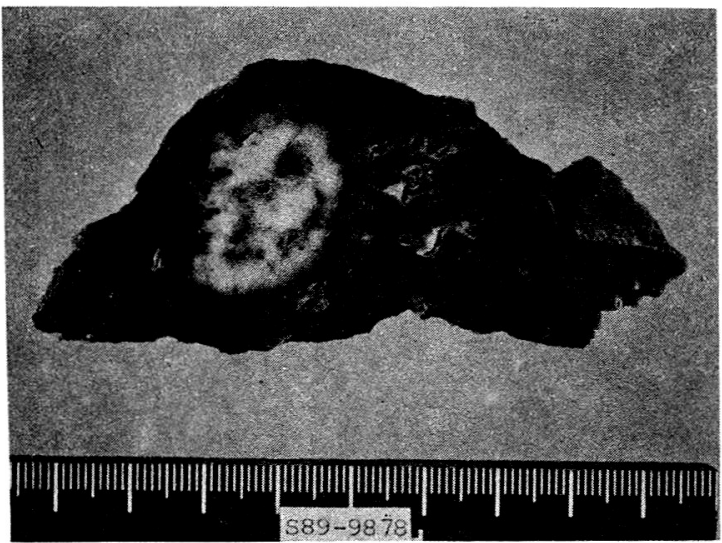

Fig. 5. Gross appearance of the lung, showing well defined round tumor mass $(4.5 \times 3.5 \mathrm{~cm})$ filled with necrotic material and blood. Central portion of the mass was finely granular with cystic change.

증가에 따라 그 중심부위에 허혈성 괴사가 일어나는 경 우, 넷째, 항암제나 부신피질 호르몬제, 또는 방사선 치 료등에 의해 종양의 괴사가 일어나는 경우, 다섯째, 분 명하지는 않으나 종양에서 분비되는 단백분해효소등에 의한 자가탐식작용(autophagism) 등이 그 기전으로 생 각되고 있다.

본 증례는 흡연력이 길지 않은 약년 남성 홉연자에서 $\mathrm{X}$ 선검사상 폐에 벽이 얇은 공동성 병변이 나타나 폐결
핵에 의한 공동이나 기관지 낭종등의 양성질환을 의심하 였다가, 객담세포진검사 및 수술후 조직검사에서 원발 성 폐선암으로 진단된 예였다.

병리학적 소견상 X선상 공동으로 보였던 부위에서는 다발성의 미세괴사(micronecrosis) 와 중성구의 침윤 및 출혈소견이 있었으며, 선포내에 다량의 분비물을 함유 한 암세포 및 암세포의 상피층에서의 위축이 관찰되었 다. 공동의 벽으로 보였던 부위에서는 강내(luminal)의 분비물은 비교적 적고 키가 큰 원주상피세포(columnar epithelial cell)의 형태를 가지는 암세포의 침윤이 관찰 되었으며, 괴사가 심함에도 불구하고 염증소견은 심하 지 않았다(Fig. 5,6,7).

원발성 폐암에서의 공동의 발현빈도는 Bateson등이 고립된 국한성 (solitary, circumscribed) 폐암 100예에 서 12예 (12\%) 를 보고한 이래 ${ }^{8)}$, Lechar등은 563예중 3 예 $(0.53 \%)^{9)}$, Chadhuri등은 폐절제술 또는 부검을 시 행한 631예중 100예(15.8\%)에서1), Theros는 말초성 (peripheral) 폐암 1267예중 79예 (6.47\%)에서 ${ }^{10)}$ 공동 을 발견하였다고 보고하였다. 국내에서는 유등이 단순 흥부X선찰영을 시행한 200 예중 4 예 $(2 \%)^{11)}$, 김등이 훙 부 전산화단층촬영을 시행한 183 예중 12 예 $(7 \%)^{12)}$ 에서 공동을 발견하였다고 보고하였다.

저자에 따라 발견 빈도에 차이가 있는 것은 $\mathrm{X}$ 선검사 당시의 병변의 진행정도와 방사선 검사술의 발달로 크기 가 작거나, 단순 훙부칠영시 보이지 않던 병변까지 발견 할 수 있게된 점등과 연관이 있을 것으로 생각된다.

공동의 벽은 대체로 두꺼우며 Chadhuri등이 보고하 였던 공동성 폐암 10 예중 본 증례에서와 같이 벽이 얇았 던 경우는 3 예에 불과하였고 그중 1 예만이 선암이었 다 ${ }^{10)}$.

원발성 폐암의 공동은 대개는 단일성이지만 다발성으 로 나타난 경우도 보고되어 있다).

세포형에 따른 공동형성의 빈도를 보면 2 $16 \%$ 로 편 평상피세포암에서 가장 빈번히 나타난다고 하며, 선암 에서는 비교적 적어 ${ }^{13)}$, Theros는 선암 170 예중 11예 $(6.47 \%)^{10)}$, Woodring등은 100 예중 6 예 $(6.0 \%)$ 에서 보고하였다.

편평상피세포암에서 공동형성이 잘 일어나는 이유로 는, 정상상피세포에서와 같이 각화층의 탈락이 일어나 기 쉽기 때문이라는 학설과, 혈액공급에 비해 종양의 성 장속도가 빨라서 종양의 중심부에서 허혈성 괴사가 일어 

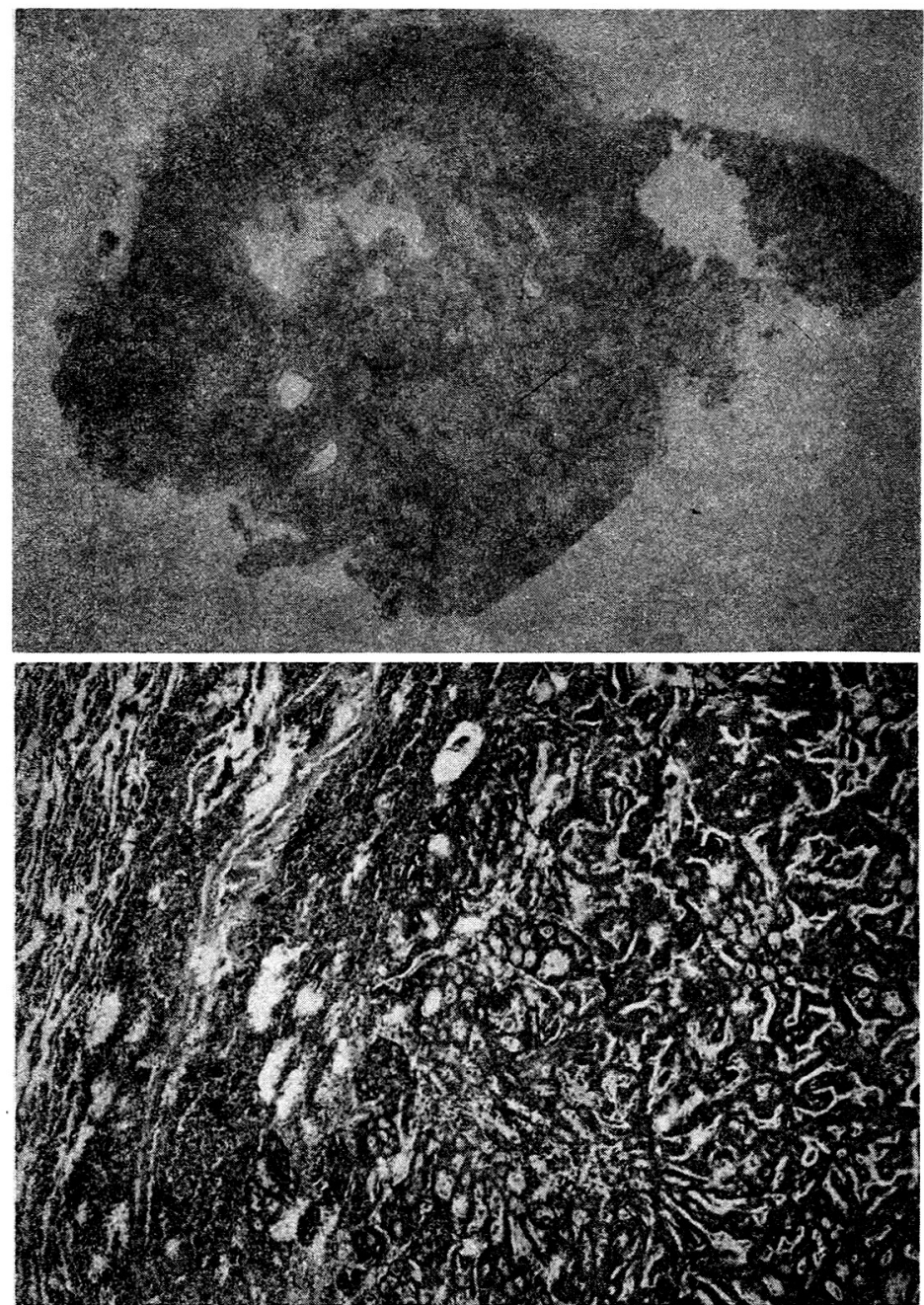

Fig. 6,7 Microscopic Appearance $(H \& E \times 100)$. $(H \& E \times 400)$. central portion: multifocal micronecrosis with neutrophilic infiltration and hemorrhage mid-portion: intra-acinar secretion and epithelial atrophy of tumor cells, correlating with cavitary portion in chest films. peripheral portion: infiltrative tumor with tall columnar epithelial cells.

나기 쉅기 때문이라는 학설이 있다.

Bernhard등에 따르면 폐결핵이외의 공동성 병변을 가진 212 명의 환자중 19 예가 $(8.96 \%$ ) 폐암에 의한 공동 이었다고 하며, 이런 경우에도 항생제, 기관지 확장제, 자세 배농법등의 치료를 하면 자각증상과 $\mathrm{X}$ 선상의 호전 을 나타낼 수 있다고 한달)

폐암에 병발된 공동을 의심하게 하는 $\mathrm{X}$ 선 소견으로는
일반적인 호발부위외에 생긴 폐농양이나 공동, 주변 늑 골의 골파괴, 농양이나 공동의 내벽이 불규칙한 경우, 충실성 종괴 (solid mass)에서 중심외의 (eccentric) 공 동형성이 있는 경우 등이 있달.

본 증례는 흡연력이 비교적 적었고, 나이도 젊었으며, $\mathrm{X}$ 선상에서도 벽이 비교적 얇은 공동을 보였지만 폐선암 에 병발된 공동으로 진단된 예였고, 따라서 임상적으로 
비록 양성질환에 의한 공동의 소견을 보이는 경우라고 해도 악성일수 있으므로, 진단이 불분명한 공동성 병변 이 있는 경우에는 필요하다면 시험적 개홍술등의 관혈적 (invasive) 검사를 시행하여 조기진단과 적절한 치료를 시행하여야 할 것으로 사료된다.

\section{결 론}

저자등은 흡연력이 비교적 짧은 약년 남성흡연자에 서, $\mathrm{X}$ 선소견상 벽이 비교적 얇은 공동성 병변으로 표명 되었던 원발성 폐선암 1 예를 경험하였기에 문헌고찰과 함께 보고하였다.

\section{REFERENCES}

1) Chadhuri MR: Primary pulmonary cavitating carcinomas. Thorax 28:354, 1973

2) Bernhard WF, Malcom JA, Wylie RH: The carcinomatous abscess. New Eng J Med 266:914, 1962

3) Bailey A: The epidemiology of bronchial carcinoma. p11-22, Berlin, Springer-Verlag, 1987

4) 대한민국 보사부 : 한국인 암 등록 조사자료 분석보고 서. $18: 59,1986$
5) 유빈, 정희순, 한성구, 심영수, 김건열, 한용철 : 약 년자 폐암의 임상적 관찰. 대한내과학회잡지 32:659, 1987

6) Churg A: Tumors of the lung, In Thurlbeck WM (Ed), Pathology of the lung, p322, New York. Thieme Medical Publishers Inc. 1988

7) Berger M, Thompson JR: Cavitary carcinomatosis of the lungs. Dis Chest 52:111, 1967

8) Bateson EM: The solitary circumscribed bronchogenic carcinoma. Brit J Radiol 37:603. 1964

9) Lehar TJ, Carr DT, Miller WE, Payne WS, Woolner LB: Roentgenographic appearance of bronchogenic adenocarcinoma. Am Rev Resp Dis 96:247. 1967

10) Theros EG: Varying manifestations of peripheral pulmonary neoplasms. Am J Roentgenol 128:897. 1977

11) 유형식, 최경희, 성기준, 최병술 : 숸발싱 폐암의 방 사선학적 고찰. 대한 방사선의학회지 13:382. 1977

12) 김교연, 최규옥: 원발성 폐암의 세포형에 따른 전산 화 단층찰영상의 분석. 대한 방시서ㄴㅓㅢ학회지 24:1028. 1988

13) Pare JAP, Fraser RG: Synopsis of the disease of the chest. 1st Ed p400-410, Philadelphiä, Saunders, 1983

14) Woodring JH, Stelling CB: Adenocarcinoma of the lung. Am J Roentgenol 140:659, 1982

\section{$=$ Abstract $=$}

\section{Cavitary Lung lesion in a Young Male}

Dong Chull Choi, M.D., O Jung Kwon, M.D., Sung Koo Han, M.D.

Young Soo Shim, M.D., Keun Youl Kim, M.D. and Yong Chol Han, M.D.

Department of Internal Medicine, Seoul National University, College of Medicine, Seoul, Korea

Jung Gi Im, M.D.

Department of Radiology

Sook Whan Sung, M.D.

Department of Thoracic Surgery

Jeong Wook Seo, M.D.

Department of Pathology

We have experienced a case of thin walled, cavitary, primary adenocarcinoma of the lung in a young male smoker.

We confirmed it with sputum cytolgoy and pathology of surgical specimen.

So, we present a case with the brief review of literatures. 